\title{
Major and trace element partitioning between mineral phases in diamondiferous and non-diamondiferous eclogites from the Udachnaya kimberlite pipe, Yakutia
}

\author{
Spetsius, Z.V.1 ${ }^{1}$ Taylor, W.R. ${ }^{2}$, and Griffin, B.J. ${ }^{3}$ \\ 1. Institute of Diamond Industry, Mirny, Yakutia, 678170, Russia \\ 2. RSES, Australian National University, Canberra, A.C.T. 0200, Australia \\ 3. Centre for Microscopy and Microanalysis, University of Western Australia, Nedlands, WA, 6907, Australia
}

\section{Introduction.}

Knowledge of trace element distributions in mineral phases from mantle eclogites, which is one of the principal lithologies in which diamonds occur, are useful in deciphering their complicated history and evolution (e.g., Ireland at al., 1994; Taylor at al., 1997). There are two principle targets of our investigation: 1) the study of REE abundance in primary rockforming minerals of eclogite xenoliths from the Udachnaya pipe with particular attention to differences between diamondiferous and barren eclogites; and 2) the study of the major and trace element composition of second generation minerals which often surround diamond grains in eclogite xenoliths. Such a study can provide important information on the chemical environment of mantle eclogites including the nature of the original eclogite protolith and subsequent events that may have affected the eclogite including partial melting, diamond formation, metasomatic overprinting, and in some cases late-stage processes which have caused growth of second-generation minerals, including diamond (Spetsius, 1995).

\section{Samples}

The trace element composition of minerals from a suite of 24 mantle eclogites and related xenoliths from the Udachnaya pipe have been investigated. Five of the samples are nondiamond-bearing bimineralic eclogites or kyanite eclogites. The remaining xenoliths are all diamondiferous and include mostly bimineralic eclogites with one garnet clinopyroxenite and two garnetites (Cpx content $<1 \%$ ). Bimineralic eclogites include Fe-rich and $\mathrm{Mg}$-rich varieties (Spetsius, 1995). Trace elements have been measured by laser ablation ICPMS (LAM) at RSES, Canberra. Core and rim analyses of garnet grains show that they are generally homogeneous in both major and trace elements. For some xenoliths, trace elements abundances in kyanite, phlogopite, rutile and second generation clinopyroxene were also investigated. In metasomatized and partially melted xenoliths the fresh relicts of primary Gnt and Cpx were chosen for analysis.

\section{Results and Discussion}

Garnet: The chondrite-normalized REE patterns of Gnt usually has a convex upward shape and may vary from slightly to strongly enriched in LREE. On the basis of the REE patterns, three different types of Gnt can be distinguished. Type-1: a 'normal' group with convex upward REE pattern and steadily increasing HREE abundances from Dy to Lu (Figs 1,4); Type-2: a 'HREE-depleted' group in which the HREE show no marked increase from Dy to Lu (Fig. 2); and Type-3: an 'Eu-anomalous group' in which there is a small positive Eu anomaly and a generally flat or slightly decreasing HREE pattern (Fig. 3). With the exception of Gnt from sample Ud-220 which is rich in trace elements, the content of most REE in Gnt is similar.

Clinopyroxene: Cpx is characterised by high LREE abundances relative to the HREE with chondrite normalized patterns generally peaking at $\mathrm{Ce}, \mathrm{Pr}$ or $\mathrm{Nd}$. Overall REE patterns are generally complementary to those of coexisting garnet, e.g. Cpx coexisting with Type-2 garnet is HREE depleted (Fig. 2) and Cpx coexisting with Type-3 garnet has a positive Euanomaly (Fig. 3). In the type-3 case, the Eu anomalies are probably inherited from a plagioclase-accumulative precursor rock, e.g. an original gabbro. Wide variations in $\mathrm{Sr}$ content are found in clinopyroxene; Sr content generally correlates with REE abundance in eclogites with Type-1 and -2 Gnt but is inversly correlated for eclogites with type-3 Gnt suggesting possible metasomatic introduction. Cpx from sample Ud-211 differs from other Cpx samples by enrichment in Sr, Ba and middle REE; and Cpx from Ud-220 has high 
HREE contents. Variable LREE enrichment of primary Cpx suggest widespread cryptic metasomatism and this confirms the results of petrographic observation (Spetsius, 1995). Eclogitic Cpx from non-diamondiferous xenoliths differs by slightly higher contents of LREE (Ce to $\mathrm{Nd}$ ) and $\mathrm{Sc}$, and by higher $\mathrm{Ce} / \mathrm{Lu}$ ratios (Fig. 4) but there are too few samples to provide a definitive distinction.

Fig.1 Ud160 Type-1

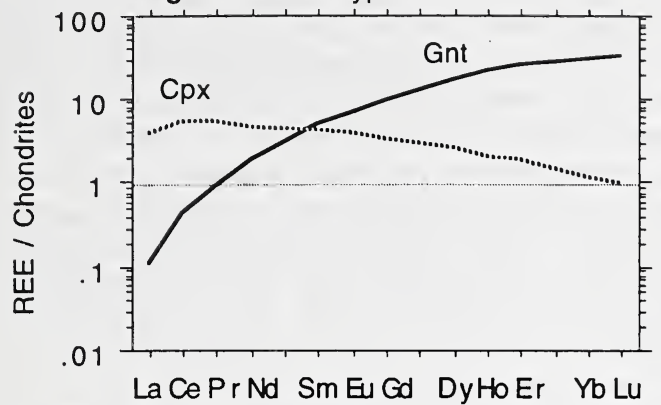

Fig. 3 Ud137 Type-3

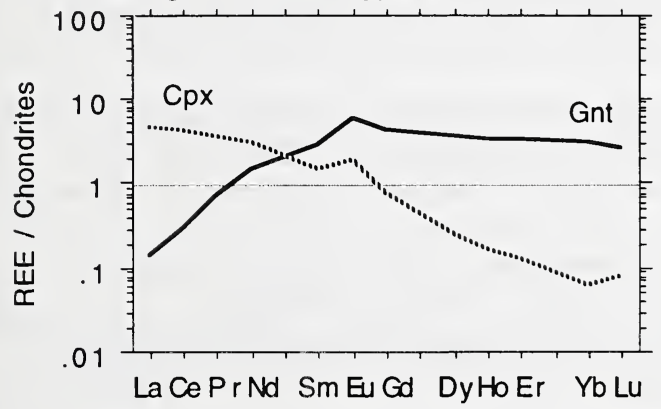

Fig.2 Ud162 Type-2

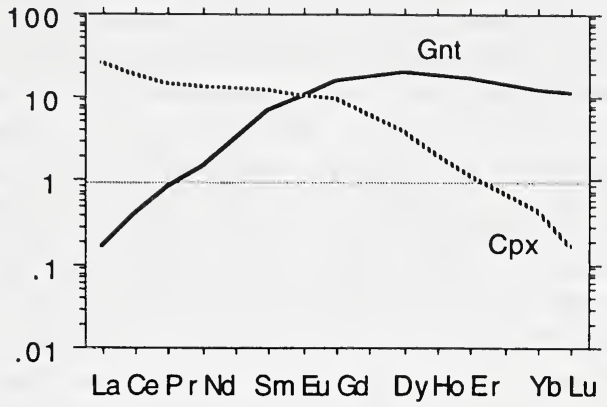

Fig.4 U2260 Type-1 (non-diam.)

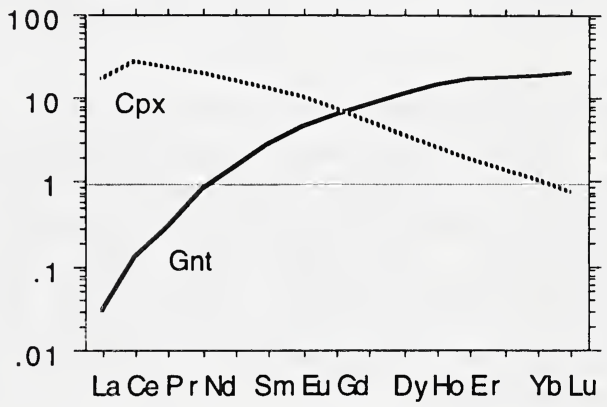

Figures 1-4: REE patterns for Gnt and Cpx from diamondiferous (Figs 1-3) and non-diamondiferous (Fig.4) Udachnaya eclogite xenoliths showing three distinctive types.

In garnet pyroxenite U-759 both Gt and Cpx differ in REE and Sr content from those minerals in the bimineral eclogites suggesting the pyroxenite has a rather different origin. The second generation pyroxenes, which were mostly captured as inclusions by diamonds, tend to be enriched in $\mathrm{REE}, \mathrm{Zr}, \mathrm{Pb}$ and $\mathrm{Th}$; they also have a high content of $\mathrm{Hf}$ and some are enriched in $\mathrm{P}, \mathrm{Sr}$ and $\mathrm{Ba}$. Rutiles were measured in two samples and in both cases they contain very high $\mathrm{Nb}(>200 \mathrm{ppm})$ and $\mathrm{Zr}(>1000 \mathrm{ppm})$ and moderate $\mathrm{Hf}$ and $\mathrm{Ta}$. Phlogopite has high $\mathrm{Ba}(\sim 400 \mathrm{ppm})$ and $\mathrm{Nb}(\sim 20 \mathrm{ppm})$ contents and also rather high $\mathrm{Ni}(\sim 500 \mathrm{ppm})$ but displays a depletion in all $\mathrm{REE}$ relative to $\mathrm{Cpx}$.

A set of Cpx / Gnt partition coefficients (D) have been calculated for the trace elements. The order of compatibility with $\mathrm{Cpx}$ is $\mathrm{Sr}>>\mathrm{Ni}>\mathrm{Nd}>\mathrm{V}>\mathrm{Ta}>\mathrm{Hf}>\mathrm{Pb}>\mathrm{Nb}>\mathrm{Ga}>\mathrm{Ti}, \mathrm{Cr}>$ $\mathrm{Zr}, \mathrm{Zn}>\mathrm{Gd}>\mathrm{Co}>\mathrm{Sc}, \mathrm{P}>\mathrm{Y}>\mathrm{Yb}$, Lu. To investigate correlations of $\mathrm{D}$ as a function of temperature we have used the Ellis and Green (1979) thermometer to estimate the equilibration $\mathrm{T}$ of Gnt and Cpx pairs. Temperature, pressure and major-element mineral composition to a large extent control trace element-partitioning behaviour in the eclogite minerals (O'Reilly and Griffin, 1995). In this study the partitioning of HREE and Y between Gnt and Cpx correlates with both Ca content and Mg\# of Gnt. The partitioning of Ga and Hf shows a negative correlation with Gnt Mg\#. All D values show very weak or no dependence against Cpx Mg\#. The Cpx-Gnt partitioning of $\mathrm{V}, \mathrm{Zr}$, Ga and especially Ni show negative correlations with T. The D-values for elements such as $\mathrm{Ti}, \mathrm{Cr}, \mathrm{Y}$ and $\mathrm{Ga}$ are similar to those determined by O'Reilly and Griffin (1995) for eclogites from South Africa, but differ for Sr, $\mathrm{Zr}, \mathrm{Ni}$ and some others. The partianing of most REE between Cpx and Gnt shows a 
negative correlation with $\mathrm{Na}$ and $\mathrm{Al}$ content or with the Jd content of Cpx. D-values for Ga, $\mathrm{Cr}$ and $\mathrm{V}$ show positive correlations with the Jd-component because these elements subtitute as the trivalent ions and require $\mathrm{Na}$ as a counter-balancing cation.

\section{Conclusions}

Diamondiferous xenoliths do not seem to stand out from the general suite of eclogite xenoliths either in terms of their major element chemistry (Spetsius, 1995) or the abundance of trace elements in Gnt and Cpx. Partition coefficients of REE and other trace elements between coexisting Gnt and $\mathrm{Cpx}$ are evidently influenced by major element composition and show P-T dependence. The substitution of $\mathrm{Sr}, \mathrm{Ba}$ and some other elements into Gnt and $\mathrm{Cpx}$ does not appear to be controlled by $\mathrm{P}, \mathrm{T}$ or bulk composition of the minerals. These observations indicate that some trace elements behave independently, supporting the suggestion of Spetsius and Griffin (1997) that enrichment or depletion of some trace elements in eclogitic minerals from Udachnaya is due to complicated metasomatic and partial melting events. Trace element abundances in secondary pyroxene included in diamonds indicates that these phases are enriched in many REE and other incompatible elements, most probably as a result of metasomatism and partial melting. A second phase of diamond growth in some xenoliths seems to be linked to this mantle metasomatic event. REE abundances in coexisting Gnt and $\mathrm{Cpx}$, and $\mathrm{Cpx} / \mathrm{Gt}$ partition coefficients for some trace elements in eclogite xenoliths from Udachnaya are similar to those found by O'Reilly and Griffin (1995) for eclogites from South Africa, but differ for $\mathrm{Sr}, \mathrm{Zr}$ and probably $\mathrm{Ni}$ which suggest some distinction in the evolution of the Siberian and South African mantle.

\section{References}

Ireland, T.R., Rudnick, R.L., Spetsius, Z.V., 1994, Trace elements in diamondinclusions from eclogites reveal link to Archean granites, Earth Planet. Sci. Lett., 128, p. 199-213.

Spetsius, Z. V., 1995, Occurrence of diamond in the mantle: a case from the Siberian Platform, Jour. Geochem. Expl., 53, p. 25-39.

Spetsius, Z.V., and Griffin, W.L., 1997, Trace elements in minerals from eclogites from Udachnaya kimberlite pipe, Yakutia, Russ. Geol. Geophys., 38(1), p. 240-246.

O'Reilly, S. Y., and Griffin, W. L., 1995, Trace - element partitioning between garnet and clinopyroxene in mantle-derived pyroxenites and eclogites: P-T-X controls, Chem. Geol., 121, p. 105-130.

Taylor, L. A., Snyder, G. A., Crozaz, G., Sobolev, V. N., Yefimova, E. S., and Sobolev, N.V., 1996, Eclogitic Inclusions in diamonds: Evidence of complex mantle processes over time, Earth Planet. Sci. Lett., 142, p. 535-551. 